\title{
KONSEPSI SISWA PADA SUATU BENTUK BANGUN RUANG TERKAIT DENGAN RUSUK DAN DIAGONAL SISI
}

\author{
Rosilawati $^{1}$, Fiki Alghadari ${ }^{2}$ \\ ${ }^{1}$ SMA Negeri 1 Tanjungpandan Belitung \\ ${ }^{2}$ STKIP Kusuma Negara Jakarta \\ alghar6450@gmail.com
}

Penerimaan : 30 Agustus 2018

Diterima: 30 Desember 2018

\begin{abstract}
ABSTRAK
Penelitian ini bertujuan untuk menganalisis konsepsi siswa pada bentuk bangun ruang limas terkait dengan panjang semua rusuk yang sama dan memiliki diagonal sisi. Penelitian ini merupakan survei kualitatif. Sampelnya adalah siswa kelas XII-IPS di satu Sekolah Menengah Atas Kabupaten Belitung tahun pelajaran 2018/2019. Siswa menyampaikan konsepsinya dengan cara menjawab pertanyaan survei. Analisis konsepsi siswa difokuskan pada pemahaman konsep dan objek mental bangun ruang yang ada dalam pikirannya. Hasil analisis dari respon siswa menemukan ada tiga tipe konsepsi yang teridentifikasi, yaitu konsepsi siswa yang menunjukkan kesiapan intelektual, konsepsi yang mengarah pada hambatan epistemologis, dan konsepsi yang menunjukan miskonsepsi. Pemahaman pada konsep dasar dan keluasan jaringan informasi konsep menjadi syarat untuk mempelajari konsep lanjutan suatu materi matematika, agar siswa terhindar dari miskonsepsi, sehingga pembelajaran mampu menghadirkan pengalaman konseptual dan perseptual.
\end{abstract}

Kata Kunci : bangun ruang, hambatan epistemology, miskonsepsi, pemahaman.

\section{PENDAHULUAN}

Dalam penelitian pendidikan matematika, pendekatan pembelajaran sering menjadi faktor penentu yang memberi pengaruh pada peningkatan kompetensi siswa. Memang faktor pembelajaran akan menimbulkan dampak, tetapi normalnya bahwa yang merasakan dampak itu tidak untuk keseluruhan siswa, karena secara alamiah mungkin mengalami situasi yang disebut sebagai kesulitan belajar (Dedy \& Sumiaty, 2017). Penelitian yang demikian menunjukan bahwa seluruh sampelnya dinyatakan telah siap untuk menerima pembelajaran tanpa terlebih dahulu memperhatikan tiga factor penyebab munculnya hambatan belajar. Tiga factor tersebut diantaranya seperti hambatan ontogeny (terkait dengan kesiapan mental siswa), hambatan didaktis (terkait dengan pembelajaran yang diberikan guru), dan hambatan epistemologis (terkait dengan pengetahuan siswa dalam konteks yang terbatas) (Alfian, dkk., 
2016; Dedy \& Sumiaty, 2017). Masing-masing dari ketiga factor tersebut dapat menjadi factor utama yang menghambat peningkatan kompetensi.

Peduli pada factor dan hambatan yang mungkin dialami siswa dirasakan perlu, supaya menambah intensitas terjadinya lalu lintas pengetahuan antara siswa dan guru, siswa dan siswa lain, serta siswa dan sumber belajar (Simon, 2016; Dedy \& Sumiaty, 2017). Contohnya, pada saat guru menyampaikan pembelajaran menggunakan istilah-istilah matematika, jika siswa belum memahami atau lupa dengan konsep dari istilah tersebut, maka dapat dipastikan bahwa ada bagian informasi dalam pernyataan yang disampaikan guru seketika itu akan terlewatkan. Akibatnya, ada informasi yang diharapkan sebagai pengetahuan baru kemudian menjadi terhambat untuk langsung diserap siswa. Akibat yang lainnya yaitu ada celah konsep yang mampu menciptakan kesalahan atau miskonsepsi (Sarwadi \& Shahrill, 2014; Jusniani, 2018). Lebih lanjut, hambatan belajar yang berulang dan terus berlanjut menyebabkan kualitas pembelajaran menjadi kurang baik (Alfian, dkk., 2016; Kiswanto, dkk., 2015; Ningrum \& Budiarto, 2016; Firmansyah, 2017; Soleha, 2018).

Siswa yang merespon dengan baik dari sebelum sampai sesudah pembelajaran adalah siswa yang mengalami lalu lintas informasi dan pengetahuan, tidak terkendala oleh tiga factor yang menyebabkan hambatan belajar, serta memperoleh transfer ilmu dan mampu memahami materi pembelajaran dari guru dengan baik. Respon yang baik merupakan kondisi siswa yang menunjukan kesiapan intelektual (Syahputra, 2016; Soleha, 2018), seperti siap menerima informasi baru untuk pengembangan ilmu dan pengetahunnya. Contoh hal yang perlu disiapkan oleh siswa sebelum menerima materi baru adalah kesiapan intelektual, yaitu pengetahuan terkait dengan informasi yang akan disampaikan guru (Mursalin, 2016; Kiswanto, dkk., 2015; Syahputra, 2016; Firmansyah, 2017). Mengingat kembali pengetahuan selayaknya menjadi suatu keharusan untuk dilakukan masing-masing siswa supaya cara pandangnya dengan guru pada materi belajar tidak berbeda. Persiapan demikian paling tidak untuk kesiapan mental siswa sekaligus usaha menanggulangi hambatan ontogeni, dan mengembangkan konteks aplikasi pengetahuan sebagai usaha untuk menanggulangi hambatan epistimologi pada pembelajaran lanjutan.

Konsep materi matematika saling berkaitan dan berkelanjutan (Alfian, dkk., 2016; Syahputra, 2016; Sarwadi \& Shahrill, 2014), sehingga belajar matematika membutuhkan pengetahuan yang telah dipelajari sebelumnya, dan ini sebagai syarat untuk melanjutkan 
kepada materi pembahasan baru (Ningrum \& Budiarto, 2016; Firmansyah, 2017; Effendi, 2018; Jusniani, 2018). Kebutuhan tersebut dijadikan syarat supaya apa yang disampaikan guru dapat diterima dengan baik oleh siswa, agar guru dan siswa memiliki persepsi yang sama terhadap materi pada sumber belajar. Lebih lanjut, siswa yang paham dengan konsep, maka pengetahuan matematikanya akan mendapat kekuatan karena konsep selalu terlibat dalam setiap materi matematika (Kiswanto, dkk., 2015). Di samping itu, matematika merupakan ilmu yang bersifat universal, dan dalam definisi atau istilah matematika ada konsepnya, sehingga definisi atau istilah matematika dalam persepsi setiap individu harus memiliki konteks dan makna yang sama walaupun dibahasakan dengan cara yang berbeda (Maharani, dkk., 2017; Kiswanto, dkk., 2015; Kusaeri, 2017). Jadi, persepsi tentang materi matematika yang didasari konsep merupakan salah satu syarat supaya membentuk pengetahuan matematika yang dimiliki siswa menjadi kuat, serta kualitas belajar dan kemampuan intelektualnya meningkat (Kiswanto, dkk., 2015; Khoiri, 2014).

Persepsi merupakan fondasi awal untuk membangun pengetahuan (Bueno, 2013). Namun demikian, dalam matematika, persepsi bisa bernilai salah dan bisa pula benar. Ada persepsi yang tidak sesuai dengan konsep karena hanya berdasarkan pengalaman perseptual (Bueno, 2013). Persepsi yang melibatkan konsep-konsep sebagai alasan dasar interpretasinya merupakan suatu konsepsi. Simon (2016) mengatakan bahwa konsepsi adalah model penjelasan atau hasil penafsiran tentang suatu objek konseptual tertentu. Contohnya, gambar kubus dalam perspektif miring menyebabkan semua perpotongan rusuk tidak selalu tegak lurus. Akan tetapi, untuk setiap pasang mata yang melihat sebuah kubus yang disertai dengan fakta geometri bahwa dalam konsepsinya akan menyebutkan semua perpotongan rusuk selalu tegak lurus. Beberapa temuan penelitian terkait dengan konsepsi pada materi matematika seperti dijelaskan oleh Safrina \& Dermawan (2016) bahwa sampelnya yang berkemampuan tinggi, sedang, rendah mengalami miskonsepsi pada pengetahuan konseptual atau procedural. Selain itu, Maharani, dkk., (2017) menemukan bahwa konsepsi awal mengenai konsep bangun ruang kubus yang dikemukakan sampel studinya belum terdefinisi secara lengkap dan jelas, masih bias, dan berbeda-beda. Oleh karena itu, konsepsi merupakan awal menuju pembelajaran yang ideal untuk menghasilkan respon yang baik dari siswa (Dedy \& Sumiaty, 2017), karena belajar matematika dapat menciptakan salah satu diantara pengetahuan baru atau miskonsepsi (Maharani, dkk., 2017). Oleh karena itu, studi ini bertujuan untuk 
menganalisis konsepsi siswa pada bentuk bangun ruang limas terkait dengan panjang semua rusuk yang sama dan memiliki diagonal sisi.

\section{METODE PENELITIAN}

Studi ini dilakukan dengan pendekatan kualitatif dan metode survei pada sejumlah siswa kelas XII-IPS dari beberapa kelas di satu sekolah menengah atas Kabupaten Belitung tahun pelajaran 2018/2019. Survei ini dilakukan sebelum pembelajaran materi dimensi tiga sehingga mengetahui factor yang mungkin menjadi penyebab hambatan belajar pada siswa. Kemudian dilakukan analisis deskriptif pada respon siswa dari pertanyaan seperti berikut:

Sebuah bangun ruang dengan panjang semua rusuknya adalah $4 \mathrm{~cm}$ dan mempunyai diagonal sisi. Apakah bangun ruang tersebut berbentuk limas? Jelaskan jika iya mengapa atau jika tidak bagaimana!

Konsepsi merupakan salah satu aspek dari pemahaman konsep (Khoiri, 2014; Effendi, 2018), dan materi matematika mempelajari objek yang bersifat abstrak yang dikenal dengan objek mental (Kusaeri, 2017). Oleh karena itu, analisis konsepsi siswa difokuskan pada objek mental bangun ruang yang ada dalam pikiran siswa dan pemahaman konsepnya. Jawaban yang diberikan siswa dianalisis sehingga diketahui bagaimana konsepsi siswa pada suatu bentuk bangun ruang limas yang memiliki panjang semua rusuknya sama dan mempunyai diagonal sisi.

\section{HASIL DAN PEMBAHASAN}

Jawaban dan penjelasan yang diberikan siswa dianggap sebagai bentuk konsepsinya terhadap pertanyaan. Dari tiga kelas yang disurvei, ada sebanyak 37 siswa yang memberikan jawaban.

\section{Klasifikasi Respon Siswa dari Pertanyaan}

Berikut ini tabel sebaran jumlah siswa yang menjawab pertanyaan bahwa bangun ruang tersebut berbentuk limas atau bukan limas.

Tabel 1. Sebaran Jumlah Respon Siswa

\begin{tabular}{lc}
\hline \multicolumn{1}{c}{ Respon } & Jumlah Respon \\
\hline Bangun ruang berbentuk limas & 12 \\
Bangun ruang bukan berbentuk limas & 25
\end{tabular}


Berdasarkan table di atas, terlihat ada 12 dari 37 siswa, atau kurang lebih sepertiga dari jumlah siswa yang menyatakan bahwa bangun ruang dengan panjang semua rusuknya adalah 4 $\mathrm{cm}$ dan mempunyai diagonal sisi merupakan bangun ruang yang berbentuk limas. Sementara itu, dari 25 siswa yang menjawab bukan limas, ada 6 orang siswa yang tidak menjelaskan deskripsi tentang bentuk bangun ruang, hanya menyatakan bahwa bangun ruang bukan berbentuk limas dengan alasannya masing-masing. Keberagaman konsepsi yang diberikan siswa sesuai dengan pernyataan Rustaman (Maharani, dkk., 2017) yang menyebutkan bahwa setiap siswa telah memiliki konsep sendiri-sendiri dan berbeda-beda sebelum mengetahui konsep yang benar. Karena analisis respon difokuskan pada objek mental dan pemahaman konsep sehingga ada kemungkinan siswa menunjukan pemahaman yang benar atau salah. Oleh karena itu, konsepsi yang disampaikan siswa dikelompokan menjadi tiga, yaitu konsepsi yang menunjukkan kesiapan intelektual, konsepsi yang mengarah pada hambatan epistemologis, dan konsepsi yang menunjukan miskonsepsi.

\section{Konsepsi yang Menunjukkan Kesiapan Intelektual}

Berbagai konsepsi diberikan siswa dengan pilihan katanya masing-masing. Dari kalimat yang tersusun sebagai konsepsinya, ada yang bermakna sama dan menunjukan pemahaman pada konsep yang benar serta kesiapan intelektual untuk mempelajari konsep lanjutan.

1. Sisi tegak limas dari segitiga sama sisi dan diagonal sisinya pada bidang alas

Berdasarkan hasil survei, ada temuan dua konsepsi yang maknanya mirip namun dibahasakan dengan cara yang berbeda, yaitu dari dua orang siswa yang menyatakan bahwa bangun ruang tersebut berbentuk limas. Pertama, mengatakan bahwa limas tersebut terbentuk dari segitiga sama sisi dan diagonalnya berada pada alas. Kedua, menyatakan bahwa limas tersebut adalah limas segi empat beraturan dengan panjang rusuk yang sama dan memiliki diagonal. Konsepsi semacam ini menunjukan bahwa dalam pikirannya siswa melihat bayangan gambar limas dengan sisi tegaknya dari segitiga sama sisi, sehingga panjang rusuknya selalu sama. Kemudian disebutkan pula bahwa diagonal sisi terletak pada bidang alas, dan ini sebagai penguatan konsepsinya bahwa alas limas tidak berbentuk segitiga karena bangun datar segitiga tidak mempunyai diagonal sisi.

Umumnya, gambaran konsepsi yang diberikan kedua siswa adalah sama karena contoh objek mental dalam bidang visual masing-masing adalah seperti limas segi empat beraturan. 
Namun model penjelasannya berbeda apabila dilihat dari sudut pandang tertentu. Sudut pandang yang menjadi focus perhatian adalah ciri-ciri dari limas. Sesuai dengan pendapat Maharani, dkk. (2017) yang menyatakan bahwa konsepsi siswa tidak lain mengacu pada ciriciri dari bangun ruang. Sudut pandang konsepsi yang pertama adalah bangun datar pembentuk limas, sedangkan sudut pandang konsepsi yang kedua adalah jenis-jenis limas. Perbedaan sudut pandang ini menunjukan bahwa pengetahuaan konseptual tentang bangun ruang limas yang dimiliki masing-masing siswa menjadi ciri tertentu, dan inilah yang Simon (2016) sebut dengan konsepsi. Selanjutnya, konsepsi bersifat subjektif atau personal yang menunjukan pemahaman tentang suatu konsep (Kusaeri, 2017; Maharani, dkk., 2017; Effendi, 2018). Oleh karena itu, konsepsi yang diutarakan oleh dua orang siswa tersebut diklasifikasikan dalam kelompok konsepsi yang menunjukkan bahwa dirinya paham dengan konsep dari pertanyaan yang diajukan dalam survei dan memiliki kesiapan intelektual untuk belajar bangun ruang limas pada konsep lanjutan.

2. Semua rusuk limas sama, tetapi panjang diagonal sisi berbeda karena sesuai jenisnya

Konsepsi dari seorang siswa mengenai pertanyaan survei adalah benar bahwa bangun ruang tersebut berbentuk limas karena semua rusuk limas sama panjang dan mempunyai diagonal sisi, tetapi untuk panjang diagonalnya berbeda-beda sesuai dengan jenis limasnya. Siswa yang memberi konsepsi demikian menunjukan suatu perbedaan dibanding siswa lainnya bahwa dalam bidang visualnya tidak hanya ada limas dengan alas persegi saja yang memenuhi konsep panjang semua rusuk yang sama dan mempunyai diagonal sisi. Karena selain limas yang alas persegi, ada jenis limas yang lainnya, seperti limas segi lima atau limas segi yang lain. Lebih lanjut, konsepsi tersebut dibentuk melalui tahap kondensasi. Kusaeri (2017) mengutip bahwa tahapan kondensasi ditandai dengan munculnya konsepsi baru dengan cara mengombinasikan proses, membuat perbandingan dan generalisasi sehingga mampu menyajikan konsep secara berbeda.

Selain itu, Kusaeri (2017) menyebutkan bahwa konsepsi setiap siswa tergantung pada keluasan jaringan informasi yang dimilikinya. Sedangkan konsepsi merupakan model teoritis tentang apa yang dipikirkan, diketahui, dan dimengerti (Simon, 2016). Jadi, konsepsi siswa tersebut seakan menunjukan bahwa struktur kognitifnya telah memiliki berbagai macam keterhubungan jaringan konsep mengenai limas. Pengetahuan konsep yang luas membuat siswa tersebut mampu mengivestigasi hubungan antara bentuk dengan jenis bangun ruang dan 
panjang rusuk dengan diagonal (Jusniani, 2018), yang kemudian dijelaskan dalam hasil penafsirannya. Sesuai pernyataan Kusaeri (2017) bahwa pembentukan konsepsi matematika berlangsung secara hirarkis yakni suatu tahapan tertentu tidak akan bisa dicapai bila semua tahapan sebelumnya tidak dilalui dengan baik. Jadi, konsepsi tersebut merupakan bentuk respon yang baik sekaligus sebagai bukti kesiapan intelektual siswa untuk mempelajari konsep lanjutan tentang bangun ruang berbentuk limas.

Dalam buku sumber belajar matematika sekolah, terlihat masih jarang yang mempelajari konsep limas sampai dengan alas yang seginya lebih dari empat. Oleh karena itu, konsepsi tersebut dianggap telah dimiliki siswa berdasarkan konsep yang dirumuskan secara independen dari pengalaman belajarnya. Dengan kata lain, untuk meningkatkan konsepsi terlebih dahulu diawali dengan pemahaman konsep. Selanjutnya, siswa tersebut mendapat pengalaman konseptual setelah berpikir, menginvestigasi, dan akhirnya menemukan konsep baru beserta konsepsinya. Di sisi lain, dengan kalimat yang berbeda, Bueno (2013) mengatakan bahwa pengalaman konseptual adalah hasil yang diperoleh dari pengalaman mempelajari konsep-konsep. Inilah yang didefinisikan dalam paham konstruktivisme sebagai definsi belajar, yaitu pengetahuan tidak dibangun semata-mata dari pengalaman, melainkan perpaduan pengalaman dan struktur pengetahuan yang telah ada melalui proses asimilasi dan akomodasi (Sarwadi \& Shahrill, 2014). Manfaatnya bagi siswa sekolah menengah, membiasakan belajar melalui pengalaman konseptual akan menunjang peralihan dari pembelajaran konkrit menuju abstrak.

\section{Konsepsi yang Mengarah pada Hambatan Epistemologis}

1. Bangun ruang berbentuk kubus

Ada 18 siswa berasal dari 3 kelas yang menjawab bahwa bangun ruang tersebut bukan berbentuk limas tetapi berbentuk kubus. Hal ini menunjukan bahwa siswa memiliki pengetahuan dan konsepsi yang kuat terhadap definisi, ciri-ciri dan sifat kubus. Pengalaman belajar siswa mengenai bangun ruang telah banyak diisi dengan mempelajari materi kubus. Kondisi tersebut merupakan suatu hal yang dianggap wajar karena siswa belajar tentang kubus mulai dari sekolah dasar (Maharani, dkk., 2017). Dalam hal ini, siswa benar-benar memahami ciri-ciri suatu bangun ruang dengan semua panjang rusuknya sama dan memiliki diagonal sisi merupakan bangun ruang yang berbentuk kubus. Oleh karena itu, pengetahuan yang dimiliki siswa mempengaruhinya dalam menjawab pertanyaan (Kusaeri, 2017). 
Sebenarnya, memang tidak ada yang salah apabila siswa menjawab bahwa bangun ruang yang dimaksud dalam pertanyaan survei adalah bangun ruang yang berbentuk kubus. Akan tetapi, focus pertanyaannya adalah tentang bangun ruang limas. Jadi, identifikasi yang semestinya dilakukan siswa bukan pada bentuk bangun ruang lain selain limas. Pertanyaan survei sengaja dibuat seperti demikian dengan tujuan untuk mendeteksi adanya siswa yang berkonsepsi bahwa bentuk bangun ruang tersebut adalah kubus. Simon (2016) mengatakan bahwa konsepsi matematika memberikan peneliti pendidikan matematika alat untuk memeriksa pemahaman siswa dan memperhatikan aspek-aspek kunci dari perilaku siswa. Lebih lanjut, prilaku siswa terkait dengan konsepsi tersebut dinyatakan mengarah pada hambatan belajar tepatnya pada hambatan epistemologis. Hambatan epistemologis yaitu hambatan yang dialami siswa berkenaan dengan pengetahuannya yang memahami konsep dalam konteks yang terbatas (Alfian, dkk., 2016; Dedy \& Sumiaty, 2017). Hambatan belajar dalam hal ini adalah tentang pemahaman siswa mengenai konsep bangun ruang dengan ciri tertentu yang hanya terbatas pada suatu bentuk bangun ruang saja, dan gagal dalam menginvestigasi konsep pada bentuk bangun ruang lainnya.

2. Rusuk limas tidak semuanya sama panjang

Terdapat 8 orang siswa dari 2 kelas berbeda yang menanggap bahwa bentuk bangun ruang tersebut bukan merupakan limas, alasannya karena semua rusuk limas tidak selalu sama panjang. Tentu bahwa pemahaman pada konsep bangun ruang limas yang dimiliki siswa atas dasar pengalaman belajarnya yang secara visual melihat berbagai model dengan ukuran rusuk yang selalu berbeda. Seperti yang dinyatakan Kiswanto, dkk. (2015) bahwa persepsi siswa mengacu pada focus perhatiannya berdasarkan informasi yang diperoleh. Di samping itu, objek mental yang hadir dalam bidang visual siswa berdasarkan pengalaman perseptual (Bueno, 2013). Oleh karena itu, konsepsi tersebut menunjukan bahwa konsep memiliki asalusul dalam pengalaman belajar, dan siswa-siswa yang memiliki konsepsi seperti ini dikatakan Bueno (2013) sebagai para empiris karena konsep yang diperoleh merupakan hasil dari interaksi dengan lingkungannya.

Konsepsi tersebut sebenarnya hanya berlaku untuk bentuk limas yang panjang rusuknya tidak selalu sama, dan itu adalah hasil dari identifikasi pada pengalaman belajarnya, sehingga siswa menganggap bahwa ciri-ciri bangun ruang dengan panjang semua rusuk sama dan memiliki diagonal sisi seperti limas segi empat beraturan tidak mungkin ada. Oleh karena 
itu, konsepsi seperti ini mengarahkan siswa pada hambatan epistemologis, yaitu keterbatasan siswa dalam memahami berbagai bentuk limas berdasarkan ukuran panjang rusuk dan kepemilikan diagonal sisi. Lebih lanjut, Dedy \& Sumiaty (2017) mengatakan bahwa kondisi ini sebagai akibat dari belajar yang hanya didasarkan atas pemahaman tekstual sehingga menjadi miskin makna dan konteks. Kondisi ini biasa terjadi ketika siswa hanya belajar meniru contoh yang sudah ada, namun tidak memahami konstruksi konsep secara keseluruhan dan bukan merupakan hasil pemikiran sendiri. Akibatnya, pemahaman siswa pada konsep bangun ruang limas belum baik secara keseluruhan. Selain itu, pemahaman yang kurang baik akan menghambat proses belajar geometri selanjutnya (Kiswanto, dkk., 2015; Firmansyah, 2017).

Dampak dalam proses belajar yang mungkin terjadi adalah munculnya miskonsepsi untuk bentuk bangun ruang limas segi empat beraturan, karena limas segi empat beraturan tidak teridentifikasi sebagai bangun ruang yang memiliki panjang semua sisi yang sama dan ada diagonal ruang, sehingga berpotensi menciptakan konflik kognitif. Misalnya ketika ada siswa lain yang memiliki konsepsi berbeda dan benar, yaitu seperti limas bisa terbentuk dari segitiga sama sisi dan diagonal sisinya berada pada bidang alas yang persegi. Miskonsepsi adalah ketidaksesuaian antara pengetahuan awal siswa tentang suatu konsep dengan konsep yang akan dipelajarinya dikarenakan ada hal yang bertentangan dengan konsep menurut para ahli (Mursalin, 2016; Ningrum \& Budiarto, 2016; Ainiyah, 2016). Sedangkan konflik kognitif didefinisikan sebagai konflik antara konsepsi dalam struktur kognitif (Sutopo, 2015; Ningrum \& Budiarto, 2016). Miskonsepsi yang terjadi merupakan bentuk pengalaman konseptual siswa walaupun sebelumnya pernah mengetahui ada istilah limas segi empat beraturan, namun siswa lupa dan belum menyadarinya. Seperti pernyataan yang dikemukakan Kusaeri (2017) dan Jusniani (2018) bahwa apabila ada tahapan belajar tertentu yang tidak dilaluinya, maka timbul miskonsepsi dalam memahami konsep-konsep matematika. Lebih lanjut, Sutopo (2015) menyatakan konflik kognitif akan mendorong perubahan konseptual. Oleh karena itu, perubahan konseptual terjadi berkat adanya pengalaman konseptual. Dengan demikian, belajar akan menjadi menarik dan membutuhkan waktu penyesuaian, melalui proses asimilasi atau akomodasi, karena siswa yang mengalami hambatan epistemologis mendapat pengetahuan baru dan menyesuaikan diri dengan lingkungannya. Jadi konsepsi tersebut mengarah pada hambatan epistemologis sehingga memunculkan miskonsepsi dan konflik kognitif. 


\section{Konsepsi yang Menunjukan Miskonsepsi}

1. Merupakan ciri-ciri balok dan bukan limas, karena rusuk balok sama panjang

Seorang siswa menginvestigasi pertanyaan survei pada suatu bentuk bangun ruang, yaitu balok, dengan alasan bahwa bukan limas yang memenuhi ciri-ciri kepemilikan panjang semua rusuk sama dan ada diagonal ruang. Konsepsi tersebut merupakan bentuk pandangan yang berbeda dengan dasar ilmiah dan jelas menunjukan adanya miskonsepsi antara ciri-ciri balok dan limas. Ainiyah (2016) mengutip bahwa salah satu penyebab miskonsepsi adalah penalaran yang salah. Lebih lanjut, diterangkan dalam Ningrum \& Budiarto (2016) bahwa pandangan seperti tersebut merupakan akibat dari pemahaman konsep yang lemah sehingga mengakibatkan terjadinya miskonsepsi, yaitu kesalahpahaman atau kesalahpengertian mengenai konsep suatu ilmu.

Hasil studi ini juga ada kemiripan dengan studi yang dilakukan Ningrum \& Budiarto (2016), yaitu miskonsepsi siswa yang terjadi karena tidak tepat dalam mengidentifikasi sifatsifat geometri. Namun perbedaannya terletak pada pokok materi yang dijadikan bahan untuk mendeteksi adanya miskonsepsi, studi ini focus pada bangun ruang sedangkan studi Ningrum \& Budiarto (2016) pada bangun datar. Di samping itu, sampel yang menjadi prespondennya juga berbeda karena sampel dalam studi ini adalah siswa dari Sekolah Menengah Atas. Selanjutnya, hasil studi ini mirip pula dengan hasil studi Ainiyah (2016) yang menemukan bahwa sampelnya mengalami miskonsepsi korelasional, yaitu salah dalam menentukan hubungan antara konsep setiap bangun ruang.

2. Limas tidak mempunyai diagonal sisi

Dengan alasan karena limas tidak memiliki diagonal sisi, ada 4 orang siswa yang menyatakan konsepsinya mengenai bentuk bangun ruang yang ditanyakan dalam survei bukan merupakan bangun ruang limas. Lebih lanjut, 2 dari 4 orang diantaranya menyatakan bahwa bangun ruangnya berbentuk kubus, sedangkan 2 orang yang lain tidak memberikan konsepsi tentang bentuk bangun ruang yang ada dalam gambaran visual di pikirannya. Menurut Simon (2016), konsepsi merupakan hasil tafsiran yang menjelaskan kemampuan dan keterbatasan siswa dalam hal menyimpulkan dari apa yang mereka ketahui. Selain itu, konsepsi berkaitan dengan pemahaman siswa pada suatu konsep tertentu (Maharani, dkk., 2017; Kusaeri, 2017). Atas dasar itu, diklaim bahwa konsepsi yang disampaikan siswa menunjukan keterbatasan pemahaman pada hubungan antara bentuk limas dan kepemilikian unsur diagonal sisi. 
Keterbatasan yang ditunjukan siswa sesuai dengan pendapat yang dikemukakan Kiswanto, dkk. (2015) dimana pada umumnya siswa belajar dengan cara menghafalkan definisi tanpa memperhatikan hubungan antara konsep dengan konsep lainnya.

Sebenarnya, kebanyakan siswa di sekolah menengah telah mengetahui ada istilah diagonal sisi untuk suatu bangun datar atau bangun ruang. Namun, berdasarkan konsepsi yang disampaikan oleh 4 orang siswa tersebut, ada indikasi bahwa siswa mengalami kekeliruan menggunakan istilah antara diagonal sisi atau diagonal ruang. Disimpulkan demikian karena berdasarkan faktanya bahwa ada limas yang mempunyai diagonal sisi tetapi tidak ada diagonal ruang, sementara kubus mempunyai diagonal sisi dan diagonal ruang. Karena 2 dari 4 orang siswa memandang bangun ruangnya berbentuk kubus, sehingga hal tersebut menjadi dasar anggapan siswa yang mengalami kekeliruan dalam menempatkan konsepsi tentang diagonal sisi dan diagonal ruang.

Padahal, definisi diagonal sisi sebenarnya dapat dimaknai dari kata-kata itu sendiri, yaitu diagonal yang terletak pada sebuah sisi, dan sisi yang dimaksud tersebut tidak mungkin sisi pada bangun datar karena sisi bangun datar adalah segmen garis yang tidak memuat diagonal. Diagonal sisi dalam hal ini merupakan identitas untuk diagonal yang terletak pada sebuah sisi bangun ruang. Bueno (2013) menyebut identitas merupakan konsep dasar, sehingga istilah diagonal sisi dalam pertanyaan survei merupakan sebuah identitas yang terdefinisi. Lebih lanjut, kesulitan dalam mengungkap suatu definisi dapat mengakibatkan miskonsepsi (Ningrum \& Budiarto, 2016; Safrina \& Dermawan, 2016). Oleh karena itu, 2 orang siswa yang menyatakan bangun ruang berbentuk kubus dianggap mengalami miskonsepsi dengan definisi dari istilah diagonal sisi.

Selain itu ada pula indikasi bahwa siswa hanya mengidentifikasi bangun ruang yang berbentuk limas dengan alas segitiga saja. Dengan kata lain, siswa tidak mengidentifikasi fakta dan konsep secara keseluruahan. Jika benar demikian, maka konsepsi siswa yang menyatakan bahwa limas tidak mempunyai diagonal sisi akan gagal ketika mendapat pengalaman belajar tentang limas dengan alas segi empat atau segi lainnya, baik belajar dari pengalaman konseptual maupun pengalaman perseptual. Kondisi tersebut berkenaan dengan pernyataan yang disampaikan Bueno (2013) bahwa persepsi bisa terbatas karena ada konteks yang dapat menggagalkannya. Persepsi yang terbatas mengarah pada hambatan epistemologis. Dengan demikian, ada dua kemungkinan tipe konsepsi siswa yang dapat dinyatakan untuk alasan 
konsepsi yang dikemukakan oleh 4 siswa tersebut, yaitu konsepsi yang menunjukan miskonsepsi atau konsepsi yang mengarah pada hambatan epistemologis.

\section{KESIMPULAN}

Ada tiga tipe konsepsi yang teridentifikasi berdasarkan respon yang diberikan siswa dalam survei, yaitu konsepsi siswa yang menunjukkan kesiapan intelektual, konsepsi yang mengarah pada hambatan epistemologis, dan konsepsi yang menunjukan miskonsepsi. Sudut pandang yang dijadikan focus perhatian oleh siswa dengan konsepsi yang menunjukkan kesiapan intelektual yaitu dengan cara memperhatikan bangun datar pembentuk limas, jenisjenis limas, dan hubungan diantara keduanya. Sementara konsepsi yang mengarah pada hambatan epistemologis dikarenakan tidak mengidentifikasi fakta dan konsep secara keseluruhan, pemahaman siswa mengenai konsep bangun ruang dengan ciri tertentu yang hanya terbatas pada suatu bentuk bangun ruang saja, dan gagal dalam menginvestigasi konsep pada bentuk bangun ruang lain. Selain itu, juga dikarenakan konsep yang dipahami bukan merupakan hasil pemikiran sendiri. Sedangkan hambatan yang menunjukan miskonsepsi merupakan akibat dari pemahaman konsep yang lemah, serta siswa belajar dengan cara menghafalkan definisi tanpa memperhatikan hubungan antara konsep dengan konsep lainnya.

Studi ini hanya berdasarkan hasil survei pada sejumlah kecil sampel saja dan belum dilakukan studi kasus yang lebih komprehensif untuk menjelaskan suatu fenomena yang ada. Oleh karena itu, hasil studi ini bukan suatu kepastian untuk kelompok siswa yang mengalami kesamaan kondisi, karena masih mungkin ada konsepsi siswa yang belum terungkap dan merupakan salah satu dari tipe konsepsi jenis lain yang diperoleh selain dari hasil analisis.

\section{REFERENSI}

Ainiyah, L. A. (2016). Identifikasi Miskonsepsi Siswa dalam Materi Geometri pada Pembelajaran Matematika Siswa Kelas VIII SMP Negeri 1 Punggelan. Jurnal Pendidikan Matematika-S1, 5(1), 1-10.

Alfian, H., Sugiatno., \& Hamdani. (2016). Mengatasi Hambatan Pemahaman Konseptual Matematis dengan Pendekatan Antisipasi Didaktis Materi Dalil Pythagoras di SMP. Jurnal Pendidikan dan Pembelajaran, 6(1).

Bueno, O. (2013). Perception and conception: Shaping human minds. Biosemiotics, 6(3), 323336.

Dedy, E., \& Sumiaty, E. (2017). Desain Didaktis Bahan Ajar Matematika SMP Berbasis Learning Obstacle dan Learning Trajectory. Jurnal Review Pembelajaran Matematika, 2(1), 69-80. 
Effendi, K. N. S. (2018). Penerapan Pembelajaran Advance Organizer dalam Peningkatan Kemampuan Pemahaman Matematis dan Motivasi Belajar Siswa SMK. Prima: Jurnal Pendidikan Matematika, 2(1), 33-48.

Firmansyah, M. A. (2017). Peran Kemampuan Awal Matematika dan Belief Matematika Terhadap Hasil Belajar. Prima: Jurnal Pendidikan Matematika, 1(1), 55-68.

Jusniani, N. (2018). Analisis Kesalahan Jawaban Siswa pada Kemampuan Pemahaman Matematis melalui Pembelajaran Kontekstual. PRISMA, 7(1), 82-90.

Khoiri, M. (2014). Pemahaman Siswa Pada Konsep Segiempat Berdasarkan Teori Van Hiele. Prosiding Seminar Nasional Matematika Univeristas Jember, 19, 262-267.

Kiswanto, K., Rahman, U., \& Sulasteri, S. (2015). Deskripsi pemahaman konsep materi geometri ditinjau dari kepribadian sensing dan intuition pada siswa kelas IX SMPN 33 Makassar. MaPan: Jurnal Matematika dan Pembelajaran, 3(1), 42-58.

Kusaeri, K. (2017). Terbentuknya konsepsi matematika pada diri anak dari perspektif teori reifikasi dan APOS. Jurnal Pendidikan Matematika, 1(2), 101-105.

Maharani, H.R., Ubaidah, N., \& Aminudin, M. (2017). Konsepsi Awal Siswa SMP tentang Kubus. Jurnal Pendidikan Matematika, 3(2), 22-29.

Mursalin. (2016). Pembelajaran Geometri Bidang Datar di Sekolah Dasar Berorientasi Teori Belajar Piaget. Jurnal Dikma, 4(2), 250-258.

Ningrum, R. W. \& Budiarto, M.T. (2016). Miskonsepsi Siswa SMP pada Materi Bangun Datar Segiempat dan Alternatif Mengatasinya. MATHEdunesa: Jurnal Ilmiah Pendidikan Matematika, 1(5), 59-66.

Safrina, M. \& Dermawan, P. (2016). Konsepsi Pengetahuan Matematis Mahasiswa Program Studi Pendidikan Matematika Universitas Kanjuruhan Malang Tahun 2015/2016 pada Materi Geometri. Jurnal Pendidikan Matematika, 2(1), 31-38.

Sarwadi, H. R. H., \& Shahrill, M. (2014). Understanding students' mathematical errors and misconceptions: The case of year 11 repeating students. Mathematics Education Trends and Research, 2014, 1-10.

Simon, M. A. (2016). Explicating mathematical concept and mathematical conception as theoretical constructs for mathematics education research. Educational Studies in Mathematics, 94(2), 117-137.

Soleha, S. (2018). Hubungan antara Sikap Siswa dengan Prestasi Belajar Matematika Siswa Kelas V SD Negeri Dipawangi. PRISMA, 7(1), 113-122.

Sutopo. (2015). Scaffolding pada Konflik Kognitif dalam Pemecahan Masalah Matematika. Ta'allum, 3(1), 93-108.

Syahputra, M. R. (2016). Pengaruh Persiapan Belajar Siswa terhadap Prestasi Belajar Matematika pada Pokok Bahasan Kuadrat dan Akar Kuadrat Bilangan Bulat Siswa SMP Swasta Bandung Percut Sei Tuan. Jurnal Mantik Penusa, 19(1), 79-86. 